\title{
PEMANFAATAN BANK SAMPAH SEBAGAI UPAYA PENINGKATAN PENDAPATAN MASYARAKAT DI KELURAHAN KEBONMANIS CILACAP
}

\author{
Siti Zahrotun Nisa* Dedy Riyadin Saputro \\ UIN Prof. K.H. Saifuddin Zuhri Purwokerto \\ Corresponding Author*: niszahro16@gmail.com
}

\begin{abstract}
The purpose of this activity is to reduce the accumulation of household waste so that disasters do not occur and utilize waste with the creations and innovations of the surrounding community. In addition, to increase people's income by collecting and exchanging waste every week for basic food materials. The method used is observation, interviews, and documentation. The results show that the management of the waste bank provides many benefits to the surrounding community, the environment becomes comfortable, beautiful, green, and increases the economic income of the community. This activity received support from several parties such as the Cilacap government, the PKK driving team, LKM Makmur Kebonmanis, and PLN Peduli. The conclusion of this study is that household waste can bring benefits in terms of social, economic, and environmental positive impacts from the Waste Bank in Kebonmanis Village, Cilacap. The results show that the management of the waste bank provides many benefits to the surrounding community, the environment becomes comfortable, beautiful, green, and increases the economic income of the community. This activity received support from several parties such as the Cilacap government, the PKK driving team, LKM Makmur Kebonmanis, and PLN Peduli.
\end{abstract}

Keywords: Waste Bank; Economic Value; Society Participation; Empowerment

\section{Abstrak}

Tujuan kegiatan ini adalah mengurangi penumpukan sampah rumah tangga agar tidak terjadi bencana dan memanfaatkan sampah dengan kreasi dan inovasi masyarakat sekitar. Selain itu juga untuk menambah pendapatan masyarakat dengan mengumpulkan dan menukarkan sampah setiap minggunya dengan bahan-bahan sembako. Metode yang digunakan adalah observasi, wawancara, dan dokumentasi. Hasilnya menunjukan bahwa pengelolaan bank sampah memberikan banyak manfaat terhadap masyarakat sekitar, lingkungan menjadi nyaman, asri, hijau, dan menambah pendapatan ekonomi masyarakat. Kegiatan ini mendapat dukungan dari beberapa pihak seperti pemerintahan Cilacap, tim penggerak PKK, LKM Makmur Kebonmanis, dan PLN Peduli. Kesimpulan dari penelitian ini bahwa sampah-sampah rumah tangga dapat mendatangkan manfaat dari segi sosial, ekonomi, dan lingkungan yang berdampak positif dari Bank Sampah Kelurahan Kebonmanis Cilacap.

Kata Kunci: Bank Sampah, Nilai Ekonomi, Partisipasi Masyarakat, Pemberdayaan

Siti Zahrotun Nisa, Dedy Riyadin Saputro, Pemanfaatan Bank Sampah sebagai Upaya Peningkatan Pendapatan Masyarakat di Kelurahan Kebonmanis Cilacap 


\section{PENDAHULUAN}

Penumpukan sampah rumah tangga menjadi permasalahan yang cukup genting di Indonesia. Sampahsampah yang tidak dibuang dan diolah dengan baik dapat menyebabkan bencana disetiap daerahnya. Perlu perhatian yang sangat tinggi dalam pengelolaan sampah di negeri kita.

Sampah-sampah yang tidak dikelola dengan baik menjadi penghambat aktivitas dalam kehidupan sehari-hari seperti menimbulkan bau tidak sedap, menimbulkan penyakit, menjadi sarang hewan kotor, dan memberikan kesan kumuh dalam suatu lingkungan.

Menurut Tchobanoglus, sampah didefinisikan sebagai semua limbah berbentuk padat berasal dari aktivitas manusia dan hewan yang dibuang dan diabaikan karena dianggap keberadaannya tidak diinginkan kembali dan sudah tidak bermanfaat (Harsari et al., 2016). Menurut Undang-Undang No. 18 Tahun 2008 tentang Pengelolaan Sampah, sampah merupakan sisa kegiatan sehari-hari manusia atau proses alam berbentuk padat. Sedangkan dalam Peraturan Pemerintah No. 81 Tahun 2012 tentang Pengelolaan Sampah Rumah Tangga dan Sampah Sejenis Sampah Rumah Tangga dijelaskan bahwa sampah rumah tangga adalah sampah yang berasal dari kegiatan sehari-hari di dalam rumah tangga yang tidak termasuk tinja dan sampah spesifik. Sampah sejenis sampah rumah tangga antara lain sampah rumah tangga yang berasal dari kawasan komersial, kawasan industri, kawasan khusus, fasilitas sosial, fasilitas umum, dan atau fasilitas lainnya (Saputro et al., 2015).

Pemerintahan memiliki keterbatasan dalam upaya pengelolaan sampah jika tidak didukung dengan partisipasi masyarakat sekitar. Upaya pengelolaan sampah dengan baik dan optimal harus direalisasikan demi meningkatkan kualitas hidup masyarakat yang lebih baik dan meningkatkan kesehatan masyarakat. Salah satu upaya yang dapat dilakukan adalah dengan pendirian 
bank sampah. Selain untuk mengurangi masalah yang timbul karena penumpukan sampah, juga dapat menghasilkan sesuatu yang bermanfaat seperti ditukarkan dengan bahan-bahan pokok dan perlengkapan sehari-hari (Linda, 2016).

Dalam menanggulangi dampak dan bencana yang ditimbulkan karena penumpukan sampah rumah tangga, para masyarakat berinisiatif untuk membuat program bank sampah. Dalam program ini terdiri dari penyuluhan, edukasi, pelatihan dan pelaksanaan.

Dalam pengelolaan sampah membutuhkan masyarakat yang mempunyai kreatif dan inovasi serta jiwa kewirausahawan. Jika dalam pengelolaannya tidak baik pasti akan menimbulkan dampak negatif serta bencana.

Merubah perilaku masyarakat untuk membiasakan memilah sampah berdasarkan jenisnya, serta paradigma kumpul-angkut-buang secara konsisten bukanlah suatu hal yang mudah.
Dibutuhkan sosialisasi ketegasan, dan kerjasama dari berbagai pihak termasuk pemerintahan dalam hal ini.

Penelitian ini bertujuan untuk meninjau dan mendeskripsikan tentang penanganan dan pengelolaan sampah melalui bank sampah di Kelurahan Kebonmanis Kabupaten Cilacap dari segi sosial, lingkungan dan ekonomi.

\section{METODE PELAKSANAAN}

Program bank sampah dilaksanakan di RW X Kelurahan Kebonmanis, Cilacap Utara, Cilacap. Kelurahan kebonmanis termasuk daerah perkotaan yang masih jarang ditemukan adanya lahan yang cukup luas untuk pengolahan sampah. Dengan demikian para masyarakat berinsiatif untuk membuat program bank sampah supaya penumpukan sampah rumah tangga dapat diolah dengan baik dan manfaat.

Pemilihan lokasi di daerah ini dikarenakan kesadaran masyarakat yang sangat tinggi dalam penanggulangan bencana yang ditimbulkan dari penumpukan sampah rumah tangga. 
Setiap hari Minggu, masyarakat RW X bergotong royong untuk mengelola sampah dan bekerja bakti.

Ruang lingkup penelitian dibatasi pada pengelolaan sampah yang terdapat dalam Program Kampung Ramah Lingkungan Kelurahan Kebonmanis, ditinjau dari aspek pengelolaan sampah, dampak ekonomi, sosial dan lingkungan dari Bank Sampah Kelurahan Kebonmanis Kabupaten Cilacap.

Metode penelitian dalam artikel ini menggunakan metode deskriptif dengan studi kasus Bank Sampah kelurahan Kebonmanis Kabupaten Cilacap. Metode penelitian deskriptif sebagaimana disampaikan oleh Sukmadinata adalah sebuah metode yang berusaha mendeskripsikan dan mengartikan sesuatu, misalnya kondisi atau hubungan yang ada, pendapat yang berkembang, proses yang sedang berlangsung, dampak yang terjadi atau kecenderungan yang sedang berlangsung dengan menggunakan prosedur ilmiah untuk menjawab masalah secara aktual.
Metode deskriptif yang dilaksanakan yaitu deskriptif kualitatif berupa data berbentuk kata-kata, catatan observasi, dokumen atau pernyataanpernyataan verbal sebagai hasil wawancara atau kuesioner. Penelitian menggunakan data kualitatif ini dilakukan untuk mengembangkan data yang sebelumnya sudah ada dimana hasil data kualitatif berupa kualitas atau proses pencapaian dari suatu kegiatan.

Pengumpulan data dilakukan melalui observasi, wawancara dan dokumentasi. Penjelasannya sebagai berikut:

(a) Observasi, yaitu melakukan pengamatan langsung untuk memperoleh informasi dan data yang aktual dan terkini, seperti proses pengelolaan sampah menjadi kompos dan menjadi bermacammacam barang siap pakai, transaksi penukaran sampah dengan bahanbahan pokok yang ada di warung mandiri. Kemudian hasil observasi ditulis dan didokumentasikan. 
(b) Wawancara adalah komunikasi yang terjadi dua arah antara penanya dan narasumber untuk memperoleh data dari narasumber untuk mendapatkan informasi dan keterangan yang diperlukan terhadap fokus penelitian. Wawancara ini dilakukan dengan beberapa orang yang berkaitan dengan program bank sampah, seperti dengan ketua program Kampung Ramah Lingkungan dan Sekretaris Kelurahan Kebonmanis guna mendapatkan gambaran lebih jelas dan mendalam.

(c) Penelurusan dokumentasi, yaitu cara untuk memperoleh data tertulis seperti dokumen kegiatan, kondisi sarana dan prasarana, proses dan alur kerja program bank sampah kelurahan Kebonmanis.

Metode analisis data dilaksanakan secara kualitatif, sesuai model interaktif Milles dan Hubberman yang terdiri dari 3 tahap, yaitu tahap reduksi data, pengujian atau analisis data, serta tahap penarikan kesimpulan dan verifikasi.

\section{HASIL DAN PEMBAHASAN}

Pengelolaan sampah rumah tangga perlu mendapatkan perhatian serius dari semua pihak. Sampah menjadi permasalahan yang cukup serius dan membutuhkan penanganan khusus. Karena sampah-sampah rumah tangga yang tidak diolah akan menimbukan dampak dan bencana dilingkungannya. Dengan demikian pada tahun 2012 masyarakat berinisiatif mendirikan bank sampah yang merupakan turunan dari program Kampung Ramah Lingkungan Kelurahan Kebonmanis.

Sampah menjadi salah satu penyebab timbulnya bencana seperti pencemaran lingkungan yang dapat menyebabkan kerusakan pada lingkungan. Selama ini pengelolaan sampah hanya sebatas dikumpulkan, diangkut, dan dibuang ke TPA saja. Keterbatasan lahan untuk TPA menjadi permasalahan baru, karena saat ini kondisi TPA sudah mengalami kelebihan kapasitas (Novianty, 2013). Jumlah penduduk yang terus meningkat menjadi 
penyebab utama dalam menyumbang sampah yang berasal dari sampahsampah rumah tangga yang terus bertambah hingga melebihi batas wajar.

Bank sampah mempunyai fungsi untuk menampung tabungan sampah rumah tangga yang nantinya dapat ditukarkan dalam bentuk bahanbahan pokok dan perlengkapan sehari-hari serta dapat ditukarkan dengan jasa laundry. Sampah yang tadinya dapat menimbulkan masalah dapat menjelma menjadi barang yang bernilai ekonomi yang dapat memberikan manfaat bagi masyarakat. Aspek pemberdayaan masyarakat sangat kentara dalam proses pengelolaan sampah di bank sampah (Bachtiar et al., 2015).

Hal ini berkaitan dengan pemberdayaan masyarakat. Dimana pemberdayaan adalah suatu konsep yang muncul sebagai sebuah inovasi dalam menjalankan pembangunan dalam aspek penggalian potensi sumber daya diri dan lingkungan untuk dimanfaatkan dalam peningkatan taraf hidup manusia (Warto \& Sriyanto, 2021). Tujuan pemberdayaan masyarakat yaitu mendorong terbentuknya kekuatan dan kemampuan lembaga masyarakat sehingga akan mampu secara mandiri mengendalikan dan mengelola dirinya sendiri berdasarkan kebutuhan masyarakat, serta mampu mengatasi tantangan dimasa yang akan datang (Nurhidayah, 2017).

Dalam program bank sampah Kelurahan Kebonmanis Kabupaten Cilacap terdapat 4 tahapan yaitu penyuluhan, edukasi, pelatihan dan pelaksanaan. Seperti dalam wawancara yang di lakukan penulis dengan ketua program kampung ramah lingkungan, Bapak Mohammad Nur Hidayat pada tanggal 22 Agustus 2021 dikatakan bahwa: "Kegiatan ini dimulai dengan kegiatan sosialisasi ke $R T, R W$, tokoh masyarakat guna untuk mengedukasi, kemudian pelatihan-pelatihan peningkatan kapasitas sehingga masyarakat mempunyai bekal untuk melakukan kegiatan kedepan. Setelah masyarakat mempunyai kemampuan 
yang cukup, mulailah melakukan kegiatan yang telah direncanakan dalam program bank sampah"(wawancara dengan Bapak Mohammad Nur Hidayat, 22 Agustus 2021).

Pengetahuan masyarakat tentang pengolahan sampah rumah tangga dan lingkungan pada umumnya sudah lama diakui dan disadari sebagai faktor penting yang sangat mempengaruhi kegiatan daur ulang sampah rumah tangga.

Selanjutnya para masyarakat dilatih untuk mengolah sampah dalam berbagai macam kegiatan, seperti pemilahan jenis sampah, pengolahan kompos dan pembuatan kerajinan. Setelah mempunyai kemampuan, para masyarakat mengimplementasikan kegiatan yang telah dilatih dalam setiap minggunya.

Partisipasi masyarakat sekitar merupakan bentuk keikutsertaan masyarakat dalam menjalankan program bank sampah untuk membangun dan memberdayakan masyarakat sehingga masyarakat turut andil dalam seluruh proses yang ada dalam program bank sampah (Ratiabriani \& Purbadharmaja, 2016).

Dalam kegiatan bank sampah menerapkan konsep 3R (Reduce, Reuse dan Recycle), yakni sebuah metode dalam pengolahan sampah dan dapat mengatasi masalah yang ditimbulkan karena penumpukan sampah-sampah rumah tangga. Reduce berarti mengurangi segala sesuatu yang dapat menimbulkan penumpukan sampah. Reuse berarti menggunakan sampahsampah yang masih bisa dimanfaatkan. Sedangkan, Recycle berarti mengolah kembali sampah menjadi barang yang bermanfaat dan mempunyai nilai jual (Shentika, 2016).

Pengertian bank sampah dalam Peraturan Kementrian Lingkungan Hidup 13/2021 tentang Pedoman Reduce, Reuse dan Recycle Melalui Bank Sampah, adalah suatu tempat untuk mengumpulkan dan memilah sampah yang dapat di daur ulang dan dimanfaatkan kembali sehingga memiliki nilai ekonomis. Bank sampah 
adalah kegiatan yang mengajarkan kepada masyarakat tentang cara memilah dan memanfaatkan sampah dengan baik dan bijak. Prinsip utama dari pengembangan bank sampah yaitu dengan melibatkan dan memberdayakan masyakarat (Haryanti et al., 2020).

Kegiatan yang dilakukan adalah mengumpulkan sampah rumah tangga. Masyarakat telah memilah terlebih dahulu berdasarkan jenis sampah anorganik dan sampah organik dirumah masing-masing (Selomo et al., 2016).

Berdasarkan data yang diperoleh, bank sampah Kelurahan Kebonmanis Kabupaten Cilacap merupakan sebuah kelompok masyarakat yang bertujuan memberdayakan serta meningkatkan perekonomian masyarakat melalui pemanfaatan sampah sebagai salah satu sumber pendapatan.

Bank sampah Kelurahan Kebonmanis Kabupaten Cilacap menerima hampir semua sampah rumah tangga karena tujuan dari pembuatan bank sampah ini adalah meminimalisir pembuangan sampah oleh masyarakat secara cuma-cuma. Untuk harga yang diberikan itu dapat berubah-ubah sesuai harga pasar yang tidak selalu stabil.

Berdasarkan wawancara dengan Bapak Mohammad Nur Hidayat pada tanggal 22 Agustus 2021 dikatakan bahwa "Setiap minggunya petugas bank sampah akan mendatangi satu persatu rumah wangga untuk mengambil, menimbang dan mencatat berat sampah yang telah dikumpulkan masing-masing rumah. Dalam pengumpulan sampah, dicatat berat sampah yang berhasil dikumpulkan di buku tabungan sampah yang dimiliki masih-masing masyarakat" (wawancara dengan Mohammad Nur Hidayat, 22 Agustus 2021).

Setiap masyarakat memiliki buku tabungan sampah yang digunakan untuk mencatat hasil sampah yang berhasil dikumpulkan selama satu minggu. Buku tabungan ini lah yang nantinya dapat ditukarkan dengan bahan-bahan pokok dan perlengkapan sehari-hari, yang terdapat di warung mandiri atau dengan jasa laundry 
sebagaimana dapat dilihat pada gambar 1 dan 2.

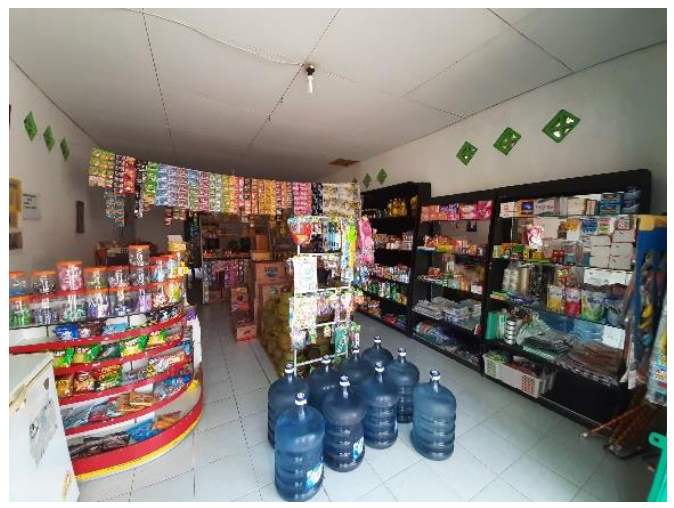

Gambar 1. Warung Mandiri untuk penukaran buku tabungan sampah dengan bahan pokok dan perlengkapan sehari-hari

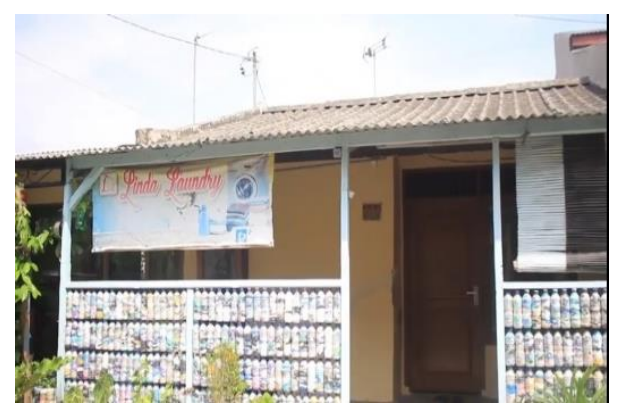

Gambar 2. Tempat Laundry untuk penukaran buku tabungan sampah dengan jasa laundry

Sampah-sampah rumah tangga yang telah diangkut menggunakan motor tiga roda khusus untuk mengangkut sampah, lalu dikumpulkan dan dipilah di Rumah Kompos yang terdapat di Taman Edukasi RW X Kebonmanis Cilacap sebagaimana pada gambar 3.

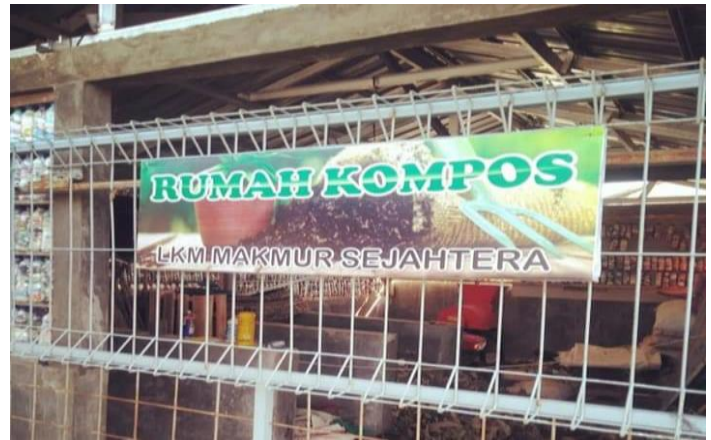

Gambar 3. Rumah Kompos sebagai tempat untuk pemilahan sampah organik dan anorganik yang telah dikumpulkan masyarakat.

Sampah organik diolah menjadi kompos sedangkan sampah anorganik diolah menjadi beberapa macam produk kerajinan, seperti tas, dompet, meja, tempat duduk, tempat pensil, dan vas bunga yang nantinya akan dijual di warung Inel Kreatif sebagaimana gambar 4 .

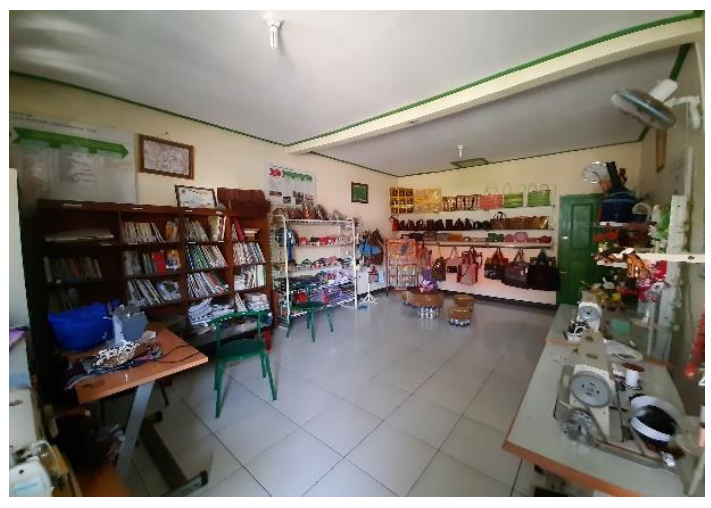

Gambar 4. Sampah anorganik yang diolah menjadi kerajinan yang siap untuk dijual di warung inel kreatif.

Salah satu bahan yang digunakan untuk mengolah menjadi kompos adalah

Siti Zahrotun Nisa, Dedy Riyadin Saputro, Pemanfaatan Bank Sampah sebagai Upaya Peningkatan Pendapatan Masyarakat di Kelurahan Kebonmanis Cilacap 
sampah organik rumah tangga. Pengelolaan sampah rumah tangga menjadi kompos memiliki beberapa manfaat yaitu mendapatkan pupuk organik yang mempunyai mutu tinggi dan mengatasi penumpukan sampahsampah rumah tangga yang menimbulkan berbagai masalah.

Pemilahan sampah organik maupun anorganik yang dikelola dengan baik dapat digunakan sebagai salah satu lapangan pekerjaan bagi masyarakat kelurahan Kebonmanis khususnya RW X, dikarenakan sampah tersebut diolah menjadi kompos dan kerajinan tangan yang memiliki nilai jual (Setyaningrum, 2015).

Sampah anorganik dibuat menjadi kerajinan-kerajinan yang dibuat oleh masyarakat RW $\mathrm{X}$ yang nantinya dijadikan hiasan dan dijual di warung inel kreatif, diantaranya yaitu pembuatan tas dan dompet dari bungkus kopi, pembuatan vas bunga dari sedotan dan botol, pembuatan meja, kursi, gapura dan tembok pembatas dari botol yang diisi dengan sampah-sampah plastik sampai penuh. Dalam pembuatan kerajinan tersebut dibutuhkan kekreatifan dan inovasi dari masyarakat setempat yang kemudian dilakukan secara bersama-sama sebagaimana pada gambar 5 dan 6 .

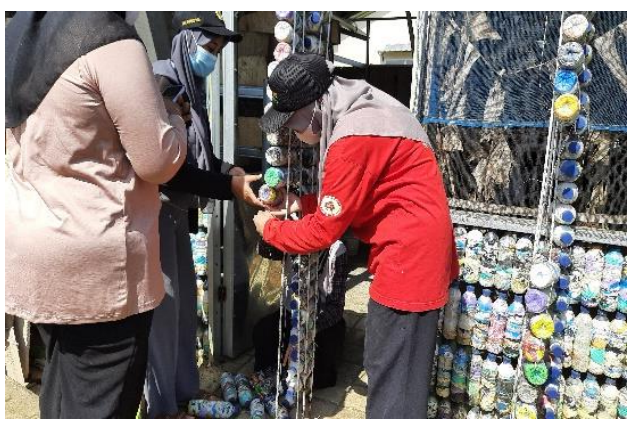

Gambar 5. Pembuatan gapura dari botol bekas yang diisi plastic

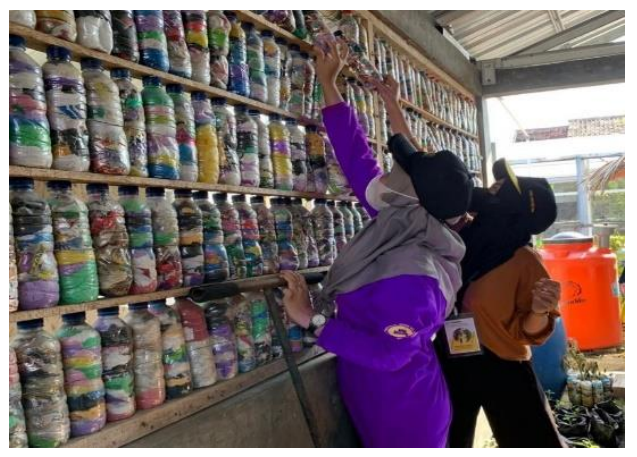

Gambar 6. Pembuatan pembatas seperti tembok dari botol bekas yang diisi plastik penuh dan disusun secara rapi

Berdasarkan pengamatan penulis, kendala yang dihadapi adalah masih banyak masyarakat yang enggan untuk memilah sampah dan lebih memilih untuk langsung membuangnya. Hal ini 
karena kurangnya kesadaran untuk bersama-sama menjaga lingkungan dari pencemaran udara dan lingkungan.

Kendala yang lain yaitu karena program bank sampah ini di daerah perumahan yang terdapat di perkotaan menjadikan lahan yang dibutuhkan kurang luas dan keterbatasan waktu karena kesibukan yang dimiliki masingmasing masyarakat. Menanggapi hal tersebut melalui wawancara penulis dengan Sekretaris Kelurahan, Ibu Heni Ekowati pada tanggal 23 Agustus 2021, dikatakan bahwa : "Kontribusi pihak kelurahan kepada kampung ramah lingkungan khususnya bank sampah adalah memberikan lahan berupa tanah bengkok untuk dipakai dan dimanfaatkan untuk kegiatan bank sampah serta mendukung segala kegiatan didalamnya" (wawancara dengan Heni Ekowati, 23 Agustus 2021).

Program bank sampah membuat lingkungan menjadi asri, hijau, dan nyaman, serta enak dipandang. Sampahsampah yang tadinya langsung dibuang ke tempat pembuangan, dapat tersaring dengan adanya bank sampah. Manfaat lain dapat dilihat dari sisi ekonominya karena dalam penukaran sampah terdapat transaksi didalamnya. Masyarakat yang telah mengumpulkan sampah rumah tangga nya akan dicatat seberapa banyak dan berat sampahnya lalu dapat ditukarkan dengan bahanbahan pokok atau perlengkapan seharihari yang ada di warung mandiri atau ditukarkan dengan jasa laundry.

Warung mandiri di bangun karena adanya dukungan dari para masyarakat dan pihak-pihak yang telah membantu dan mendukung program bank sampah agar tidak hanya memberikan manfaat bagi lingkungan saja tetapi juga dapat menambah pendapatan masyarakat, dengan dipenuhinya kebutuhan pokok sehari-hari karena partisipasi masyarakat dalam memilah dan mengumpulkan sampah yang dapat menghasilkan uang.

Program bank sampah tentunya tidak dapat berjalan dengan lancar apabila hanya mengandalkan masyarakat saja, perlu adanya dukungan dari pihak-pihak yang lain. Berdasarkan data yang diperoleh penulis program ini 
didukung oleh beberapa pihak, diantaranya adalah pemerintahan oleh LKM Makmur Kebonmanis, PLN Peduli, dan Tim Penggerak PKK.

Bank sampah mempunyai tujuan untuk memberdayakan serta untuk meningkatkan pendapatan masyarakat (Wardany et al., 2020). Bank sampah mengajarkan masyarakat untuk memilah dan mengolah sampah dengan bijak supaya dapat mengurangi sampahsampah yang diangkut ke TPA dan menambah pendapatan bagi anggota. Selain itu warga yang mengumpulkan sampah akan memperoleh tambahan pendapatan dengan terpenuhinya kebutuhan pokok dan perlengkapan sehari-hari untuk kemandirian ekonomi warga (Asteria \& Heruman, 2016).

Adanya program ini masyarakat Kebonmanis khususnya RW X merasa terbantu sekali dan merasakan manfaat yang luar biasa khususnya dalam penanggulangan bencana yang ditimbulkan dari sampah dan menggali potensi masyarakat yang ada dalam setiap kegiatan sehingga dapat menghasilkan nilai ekonomi dari pemanfaatan sampah itu sendiri.

Setelah beberapa tahun program bank sampah berjalan, disamping masyarakat melakukan kegiatan tersebut di wilayahnya, juga sudah mulai mencoba membagikan pengalamannya kepada masyarakat lain diluar wilayah Kebonmanis dengan mengadakan pelatihan-pelatihan. Menjadi narasumber baik di Kabupaten Cilacap maupun diluar Kabupaten Cilacap yang bekerja sama dengan dinas lingkungan hidup ataupun PKK Kabupaten Cilacap. Sehingga program ini bisa diterapkan di lokasi lain agar Negara Indonesia secara keseluruhan mempunyai lingkungan yang asri, hijau, dan sehat.

Berdasarkan pengamatan yang dilakukan oleh penulis terbukti masyarakat Kebonmanis, khususnya RW X dapat mengelola sampah dengan baik dimana tadinya sampah-sampah rumah tangga hanya dibuang ke TPA tanpa memperhatikan nilai ekonomi dan pemanfaatan lainnya, sekarang sudah dipilah dan mulai dimanfaatkan untuk 
kegiatan-kegiatan yang ada dilingkungan masing-masing sehingga sampah yang dibuang ke TPA lebih sedikit dan mampu menambah penghasilan masyarakat.

\section{SIMPULAN}

Pelaksanaan program bank sampah di kelurahan Kebonmanis Cilacap mempunyai tujuan untuk meningkatkan kesadaran kritis masyarakat sehingga bebas dan mampu mengatasi masalah dan mengambil keputusan secara tepat dan mandiri serta menggali potensi yang terdapat dalam dirinya. Program bank sampah yang terdapat dikelurahan Kebonmanis tidak hanya menimbulkan dampak sosial dan lingkungan seperti perilaku membuang sampah pada tempatnya, perilaku memilah dan mengolah sampah, berkurangnya penumpukan sampah rumah tangga, dan lingkungan menjadi asri dan nyaman, tetapi juga menimbulkan dampak ekonomi yaitu menambah pendapatan masyarakat dengan terpenuhinya kebutuhan pokok sehari- hari dengan kegiatan transaksi sampah yaitu sampah-sampah yang telah dikumpulkan, dipilah dan dicatat di buku tabungan sampah dapat ditukarkan dengan kebutuhan pokok yang ada di Warung Mandiri kebonmanis Cilacap ataupun ditukarkan dengan jasa laundry.

Adanya bank sampah di Kelurahan Kebonmanis Kabupaten Cilacap terbukti dapat meningkatkan pendapatan masyarakat sekitar. Upaya peningkatan yang dilakukan bank sampah di Kelurahan Kebonmanis Kabupaten Cilacap adalah dengan membantu memenuhi kebutuhan anggotanya.

\section{UCAPAN TERIMAKASIH}

Dalam penyusunan jurnal ini tidak akan terlaksananya tanpa adanya kerjasama dari Dosen Pembimbing Lapangan, Ketua Kampung Program Ramah Lingkungan dan berbagai pihak yang telah mendukung kegiatan ini, karena itulah penulis sampaikan banyak terimakasih kepada : 
1. Allah subhanahu wata'ala yang telah memberikan kelancaran dalam penyusunan jurnal.

2. Dr. Mohammad Roqib, M.Ag selaku Rektor UIN Prof. K.H. Saifuddin Zuhri Purwokerto.

3. Heni Ekowati, SE selaku Sekretaris Kelurahan Kebonmanis Cilacap

4. Mohammad Nur Hidayat, selaku Ketua Program Kampung Ramah Lingkungan.

\section{REFERENSI}

Asteria, D., \& Heruman, H. (2016). Bank Sampah Sebagai Alternatif Strategi Pengelolaan Sampah Berbasis Masyarakat di Tasikmalaya. Jurnal Manusia Dan Lingkungan, 23(1), 139.

Bachtiar, H., Hanafi, I., \& Rozikin, M. (2015). Pengembangan Bank Sampah Sebagai Bentuk Partisipasi Masyarakat Dalam Pengelolaan Sampah ( Studi Pada Koperasi Bank Sampah Malang ). Jurnal Administrasi Publik, 3(1), 130.

Ekowati, Heni. Personal Interview. 23 Agustus 2021.

Harsari, F. S., Priyambada, I. B., \& Samadikun, B. P. (2016). Studi Timbulan, Komposisi dan
Karakteristik dalam Perencanaan Teknis Operasional Pengelolaan Sampah di Rusunawa dan LPPU Universitas Diponegoro. Jurnal Teknik Lingkungan, 5(1), 2.

Haryanti, S., Gravitiani, E., \& Wijaya, M. (2020). Studi Penerapan Bank Sampah dalam Upaya Pengelolaan Lingkungan Hidup di Kota Yogyakarta. Bioeksperimen, 6(1), 63. https://doi.org/10.23917/bioekspe rimen.v5i1.2795

Hidayat, M. N. Personal Interview. 22 Agustus 2021.

Linda, R. (2016). Pemberdayaan Ekonomi Kreatif Melalui Daur Ulang Sampah Plastik (Studi Kasus Bank Sampah Berlian Kelurahan Tangkerang Labuai). Jurnal Al-Iqtishad, 1(12), 2.

Novianty, M. (2013). Dampak Program Bank Sampah Terhadap Sosial Ekonomi Masyarakat Kelurahan Binjai, Kecamatan Medan Denai, Kota Medan. Welfare State, 2(4), 4.

Nurhidayah, P. (2017). Pemberdayaan Masyarakat Melalui Bank Sampah di Dusun Serut, Desa Palbapang, Kecamatan Bantul, Kabupaten Bantul. Jurnal Pemberdayaan Masyarakat, 15(2), 4.

Ratiabriani, N. M., \& Purbadharmaja, I. B. P. (2016). Partisipasi 
Masyarakat dalam Program Bank Sampah: Model Logit. Jurnal Ekonomi Pembangunan Fakultas Ekonomi Dan Bisnis Universitas Udayana, 9(1), 54.

Saputro, Y. E., Kismartini, \& Syafrudin. (2015). Pengelolaan Sampah Berbasis Masyarakat Melalui Bank Sampah. Indonesian Journal of Conservation, 04(1), 84.

Selomo, M., Birawida, A. B., Mallongi, A., \& Muammar. (2016). Bank Sampah Sebagai Salah Satu Solusi Penanganan Samapah di Kota Makassar. Jurnal Mikmi, 12(4), 237.

Setyaningrum, I. (2015). Karakteristik Peningkatan Pengelolaan Smpah Oleh Masyarakat Melalui Bank Sampah. Jurnal Teknik PWK, 4(2), 195.

Shentika, P. A. (2016). Pengelolaan Bank Sampah di Kota Probolinggo. JESP, 8(1), 94.

Wardany, K., Sari, R. P., \& Mariana, E. (2020). Sosialisasi Pendirian "Bank Sampah" Bagi Peningkatan Pendapatan dan Pemberdayaan Perempuan di Magarsari. Jurnal Pengabdian Kepada Masyarakat, 4(2), 369.

Warto, \& Sriyanto, A. (2021). Pemberdayaan Masyarakat Melalui Pemanfaatan Lidi Kelapa di Desa Grogolpenatus
Kecamatan Petanahan

Kabupaten Kebumen. Solidaritas: Jurnal Pengabdian, 1(1), 60. 